\title{
Complete NMR Assignments of the Antibacterial Biflavonoid GB1 from Garcinia kola
}

\author{
Quan-Bin Han, ${ }^{a}$ Song-Fong LeE, ${ }^{b}$ Chun-Feng QiaO,${ }^{a}$ Zhen-Dan He, ${ }^{a}$ Jing-Zheng SonG,${ }^{a}$ \\ Han-Dong Sun, ${ }^{c}$ and Hong-Xi Xu',a \\ ${ }^{a}$ Chinese Medicine Laboratory, Hong Kong Jockey Club Institute of Chinese Medicine; Hong Kong, P. R. China: \\ ${ }^{b}$ Department of Applied Oral Sciences, Faculty of Dentistry, Dalhousie University; Halifax, Nova Scotia, Canada B3H \\ 3J5: and ${ }^{c}$ State Key Laboratory of Phytochemistry and Plant Resources in West China, Kunming Institute of Botany, \\ Chinese Academy of Sciences; Kunming 650204, Yunnan, P. R. China.
}

Received February 23, 2005; accepted May 9, 2005

From the antibacterial fraction of the roots of Garcinia kola, $3^{\prime \prime}, 4^{\prime}, 4^{\prime \prime \prime}, 5,5^{\prime \prime}, 7,7^{\prime \prime}$-heptahydroxy-3, $8^{\prime \prime}$-biflavanone (GB1) was isolated as the major constituent, whose interesting conformations were studied on the basis of its 1D and 2D NMR spectra obtained at different temperatures and in different solvents. GB1 showed antibacterial activities against methicillin-resistant Staphylococcus aureus (MRSA) and vancomycin-resistant enterococci (VRE) with MIC of 32 and $128 \mu \mathrm{g} / \mathrm{ml}$, respectively.

Key words Garcinia kola; biflavonoid; GB1; antibacterial

The nut of Garcinia kola HeCKel, native to Nigeria and Ghana, is chewed together with the kola nut by the local people before each meal to promote digestion, and is therefore called the false kola nut. It is believed to improve the flavor of anything eaten after it and even to render putrid water palatable. The beneficial effects of chewing this nut are generally thought to include the mechanical cleansing effect and anti-microbial substances in the seeds. During the initial screening of 10 common Nigerian chewing sticks for antibacterial activity, we noted the methanol extract of Garcinia kola displayed good activity. ${ }^{1)}$ Previous studies indicated that water-soluble polyphenolic compounds may be responsible for the anti-bacterial activity of $G$. kola. ${ }^{2,3)}$ However, we reported that the active components could be fractionated into the ether fraction, suggesting that a different class of compounds may be responsible for the activity. ${ }^{1)}$ Many phytochemical studies have revealed that biflavonoids are the major constituents of G. kola, and GB1 is one of the major biflavonoids. ${ }^{4-12)}$ In this study, a biflavanoid was isolated as the major component of the active fraction, which showed inhibitory effects against methicillin-resistant Staph. aureus (MRSA), and vancomycin-resistant enterococci (VRE).

However, it is difficult to identify the chemical structure of this biflavonoid due to the lack of sufficient reference data. This compound exhibits two sets of signals in its nuclear magnetic resonance (NMR) spectra at room temperature, which commonly leads to the conclusion of mixed compounds. As a single compound, it presented one spot or one

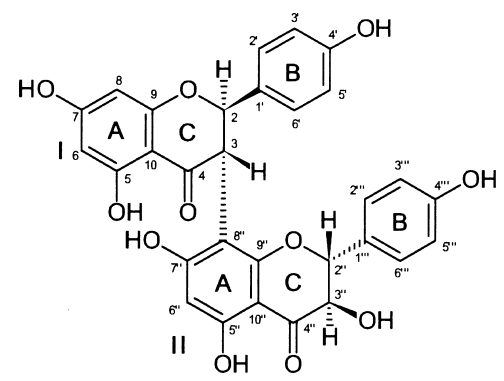

GB1 peak in various TLC and HPLC tests. The biflavonoids always present substantial spectral complexity at the dimeric level due to hindered rotation between the flavanone and the flavanonol moieties around the C-3/C-8" axis. ${ }^{4-12)}$ The confusing signals due to its rotameric behavior (atropisomerism) collapse with increasing rotation around $3 / 8^{\prime \prime}$ bond at higher temperature like $100^{\circ} \mathrm{C}$ to a single set of signals. ${ }^{13)}$ This phenomenon indicated a characteristic of this kind of 3,8"-linked biflavanoids. ${ }^{14)}$ We compared its NMR data obtained at different temperatures including $-50^{\circ} \mathrm{C},-30^{\circ} \mathrm{C}, 21^{\circ} \mathrm{C}, 70^{\circ} \mathrm{C}$, and $90^{\circ} \mathrm{C}$, and in different solvents such as acetone, pyridine, and dimethyl sulfoxide (DMSO). The results support its complicated conformations due to hindered rotation. From these analyses, we have identified this biflavonoid to be GB1 on the basis of its NMR data which was assigned ambiguously by two dimensional (2D) NMR spectra obtained at $90^{\circ} \mathrm{C}$ in DMSO- $d_{6}$. This is the first report of its complete assignment of its NMR data. In this paper, we wish to report the NMR analysis of its interesting rotameric behavior, the complete data assignment, and the related bioassays.

\section{Results and Discussion}

Compound 1, obtained as a faint brown powder, showed the $[\mathrm{M}+\mathrm{H}]^{+}$ion at $\mathrm{m} / z 559$ in its electrospray ionization mass spectroscopy (ESI-MS) corresponding to the molecular formula $\mathrm{C}_{30} \mathrm{H}_{22} \mathrm{O}_{11}$. It was identified as $3^{\prime \prime}, 4^{\prime}, 4^{\prime \prime \prime}, 5,5^{\prime \prime}, 7,7^{\prime \prime}$ heptahydroxy-3,8"-biflavanone (GB1) by ${ }^{1} \mathrm{H}-,{ }^{13} \mathrm{C}$-, and $2 \mathrm{D}$ NMR data recorded at $90{ }^{\circ} \mathrm{C}$ in DMSO- $d_{6}$. The ${ }^{1} \mathrm{H}-\mathrm{NMR}$ spectra recorded at $90^{\circ} \mathrm{C}$ showed four signals for five exchangeable $\mathrm{OH}$ protons, two at low field with $\delta=12.08$ and 11.62 , two in the range from $\delta=9.20$ to 8.80 and one upfield at $\delta=5.94$ (Table 1). The signals for two other $\mathrm{OH}$ protons recorded at $21{ }^{\circ} \mathrm{C}$ in the range from $\delta=11.20$ to 10.50 disappeared at $90^{\circ} \mathrm{C}$. Based on the ${ }^{1} \mathrm{H}-{ }^{1} \mathrm{H}$ correlation spectroscopy (COSY), and the heteronuclear multiple bond connectivity (HMBC) spectra and the coupling constants, the four doublets for eight aromatic protons at $\delta=7.16,7.07$, 6.75 , and 6.69 for one proton each with $J=8.4 \mathrm{~Hz}$ were assigned to $\mathrm{H}-2^{\prime \prime \prime} / 6^{\prime \prime \prime}, \mathrm{H}-2^{\prime} / 6^{\prime}, \mathrm{H}-3^{\prime \prime \prime} / 5^{\prime \prime \prime}$, and $\mathrm{H}-3^{\prime} / 5^{\prime}$, respectively. The doublet for two protons at $\delta=5.91(J=2.0 \mathrm{~Hz})$ 
Table 1. ${ }^{1} \mathrm{H}$ - and ${ }^{13} \mathrm{C}-\mathrm{NMR}$ Data of $\mathbf{1}$ at $21^{\circ} \mathrm{C}$ and $90{ }^{\circ} \mathrm{C}$ in DMSO- $d_{6}, \delta$ in ppm, $J$ in $\mathrm{Hz}$

\begin{tabular}{|c|c|c|c|c|}
\hline & \multicolumn{2}{|c|}{$\delta$ at $21^{\circ} \mathrm{C}$} & \multicolumn{2}{|c|}{$\delta$ at $90^{\circ} \mathrm{C}$} \\
\hline & $\delta_{\mathrm{H}}$ & $\delta_{\mathrm{C}}$ & $\delta_{\mathrm{H}}$ & $\delta_{\mathrm{C}}$ \\
\hline \multirow[t]{2}{*}{2} & $5.63, \mathrm{~d}, 11.2$ & 81.8 & $5.54, \mathrm{~d}, 11.2$ & 81.2 \\
\hline & $5.30, \mathrm{~d}, 11.2$ & 81.2 & & \\
\hline \multirow[t]{2}{*}{3} & $4.64, \mathrm{~d}, 11.2$ & 47.4 & $4.53, \mathrm{~d}, 11.2$ & 47.3 \\
\hline & $4.41, \mathrm{~d}, 11.2$ & & & \\
\hline \multirow[t]{2}{*}{4} & & 196.8 & & 195.9 \\
\hline & & 196.4 & & \\
\hline \multirow{2}{*}{$5 \mathrm{OH}$} & $12.28, \mathrm{~s}$ & 163.7 & $12.08, \mathrm{~s}$ & 163.3 \\
\hline & $12.20, \mathrm{~s}$ & 163.9 & & \\
\hline \multirow[t]{2}{*}{6} & $5.95, \mathrm{~s}$ & 96.2 & $5.91, \mathrm{~d}, 2.0$ & 95.8 \\
\hline & $5.89,{ }^{a)} \mathrm{s}$ & & & \\
\hline \multirow[t]{2}{*}{$7 \mathrm{OH}$} & $11.20-10.50^{c)}$ & 166.5 & - & 165.9 \\
\hline & & $\begin{array}{r}166.4 \\
059\end{array}$ & $591 d 20$ & 955 \\
\hline 8 & $\begin{array}{l}5.89,{ }^{a)} \mathrm{s} \\
5.85,{ }^{a)} \mathrm{S}\end{array}$ & 95.9 & & 95.3 \\
\hline \multirow[t]{2}{*}{9} & & 162.8 & & 162.4 \\
\hline & & 162.7 & & \\
\hline 10 & & 101.2 & & 101.1 \\
\hline \multirow[t]{2}{*}{$1^{\prime}$} & & 128.2 & & 127.9 \\
\hline & & 127.6 & & \\
\hline \multirow[t]{2}{*}{$2^{\prime} / 6^{\prime}$} & $7.09, \mathrm{~d}, 7.6$ & 129.1 & $7.07, \mathrm{~d}, 8.4$ & 128.1 \\
\hline & & 128.0 & & \\
\hline \multirow[t]{2}{*}{$3^{\prime} / 5^{\prime}$} & $6.74, \mathrm{~d}, 7.6$ & 114.8 & $6.69, \mathrm{~d}, 8.4$ & 114.5 \\
\hline & $6.64, d, 7.6$ & 115.0 & & \\
\hline \multirow[t]{2}{*}{$4^{\prime} \mathrm{OH}$} & $9.61, \mathrm{~s}$ & $157.6^{b)}$ & $8.80-9.20^{b)}$ & 157.2 \\
\hline & $9.51, \mathrm{~s}$ & 157.4 & & \\
\hline \multirow[t]{2}{*}{$2^{\prime \prime}$} & $5.13, \mathrm{~d}, 11.2$ & 82.6 & $5.01, \mathrm{~d}, 11.2$ & 82.4 \\
\hline & $4.96, \mathrm{~d}, 11.2$ & & & \\
\hline \multirow[t]{2}{*}{$3^{\prime \prime}$} & $4.21, \mathrm{~d}, 11.2$ & 72.4 & $4.43, \mathrm{~d}, 11.2$ & 71.7 \\
\hline & $3.99, \mathrm{~d}, 11.2$ & 72.0 & & \\
\hline 3" OH & $5.95, \mathrm{~s}$ & & $5.94, \mathrm{~s}$ & \\
\hline $4^{\prime \prime}$ & & 197.5 & & 196.6 \\
\hline \multirow[t]{2}{*}{$5^{\prime \prime} \mathrm{OH}$} & $11.84, \mathrm{~s}$ & 161.8 & $11.62, \mathrm{~s}$ & 161.7 \\
\hline & $11.72, \mathrm{~s}$ & 162.3 & & \\
\hline \multirow[t]{2}{*}{$6^{\prime \prime}$} & $5.80, \mathrm{~s}$ & 95.1 & $5.83, \mathrm{~s}$ & 94.6 \\
\hline & $5.76, \mathrm{~s}$ & & & \\
\hline \multirow[t]{2}{*}{$7^{\prime \prime} \mathrm{OH}$} & $11.20-10.50^{c)}$ & 165.1 & - & 164.4 \\
\hline & & 164.6 & & \\
\hline $8^{\prime \prime}$ & & 101.4 & & 101.2 \\
\hline \multirow[t]{2}{*}{$9^{\prime \prime}$} & & 159.4 & & 159.5 \\
\hline & & 160.1 & & \\
\hline \multirow[t]{2}{*}{$10^{\prime \prime}$} & & 100.3 & & 99.8 \\
\hline & & 99.8 & & \\
\hline $1^{\prime \prime \prime}$ & & 128.8 & & 127.2 \\
\hline & & 127.8 & & \\
\hline $2^{\prime \prime \prime} / 6^{\prime \prime \prime}$ & $7.16, \mathrm{~d}, 7.6$ & 129.0 & $7.16, \mathrm{~d}, 8.4$ & 128.3 \\
\hline & & 128.4 & & \\
\hline $3^{\prime \prime \prime} / 5^{\prime \prime \prime}$ & $6.83, \mathrm{~d}, 7.6$ & 114.8 & $6.75, \mathrm{~d}, 8.4$ & 114.5 \\
\hline & $6.64, \mathrm{~d}, 7.6$ & 115.0 & & \\
\hline $4^{\prime \prime \prime} \mathrm{OH}$ & $9.59, \mathrm{~s}$ & $157.8^{b)}$ & $8.80-9.20^{d)}$ & 157.2 \\
\hline & $9.47, \mathrm{~s}$ & & & \\
\hline
\end{tabular}

$a, b)$ Signals exchangeable, $c, d$ ) signals overlapped, — signals not exhibited.

was accordingly located at H-6, and H-8. The proton H-6" exhibited a singlet at $\delta=5.83$. In the same way, the remaining four doublets at $\delta=5.54,5.01,4.53$, and 4.43 for one proton each with $J=11.2 \mathrm{~Hz}$ were indicated to be $\mathrm{H}-2, \mathrm{H}-2^{\prime \prime}$, H-3, H-3", respectively.

In the ${ }^{13} \mathrm{C}$-NMR spectrum, ten indicative lowfield signals out of twenty-six were assigned to two carbonyl carbons, six hydroxylated carbons, and two aromatic carbons bearing oxygen-bridge to the pyran rings of the benzopyran moieties. Similarly, the signals at $\delta=82.4,81.2,71.7$, and 47.3 were assigned to C-2", C-2, C-3", and C-3, respectively. Although its absolute configuration was recently revised, ${ }^{14)}$ the complete ${ }^{1} \mathrm{H}$ - and ${ }^{13} \mathrm{C}$-NMR data assignments have not yet been reported. ${ }^{4-12)}$ This has been achieved on the basis of the ${ }^{1} \mathrm{H}$-detected heteronuclear multiple quantum coherence (HMQC), HMBC, and the rotating frame Overhauser enhancement spectroscopy (ROESY) spectra. The NMR spectra obtained at $21^{\circ} \mathrm{C}$ which seemed like two confusing sets of biflavonoids, were also assigned for the first time by $2 \mathrm{D}$ NMR analyses and comparison with those of GB2 recently available. ${ }^{15)}$ In the ROESY at $21^{\circ} \mathrm{C}$, the key OH-5 of both conformations showed nuclear Overhauser enhancement (NOEs) with H-2'", and 6"'. This observation suggested that its conformation at $21^{\circ} \mathrm{C}$ was not a simple mixture of two extremely characteristic conformations. It should be a dynamic system. The ROESY spectrum recorded a general NOE presence occurring at $21^{\circ} \mathrm{C}$ during the whole measuring time.

The NMR spectra were also measured at $70^{\circ} \mathrm{C}$. It was found that the spectra recorded at $70{ }^{\circ} \mathrm{C}$ were same as those at $90{ }^{\circ} \mathrm{C}$. The single set of signals exhibited at $90{ }^{\circ} \mathrm{C}$ would change back to those confusing data when this compound was measured again at room temperature. This suggested that its NMR spectra were associated closely with the temperature at which it was measured. Along with the rise of temperature, the hindered rotation would be faster and faster. When the temperature was beyond $70^{\circ} \mathrm{C}$, the rotation speed was too high to present any relatively stable conformation, and the spectral complexity at the dimeric level therefore disappeared. For the same reason, all of the NOEs disappeared at $90^{\circ} \mathrm{C}$ except those between $\mathrm{H}-2,3$ with $\mathrm{H}-2^{\prime}, 6^{\prime}$, and $\mathrm{H}-2^{\prime \prime}$, $3^{\prime \prime}$ with $\mathrm{H}-2^{\prime \prime \prime}, 6^{\prime \prime \prime} .{ }^{15)}$ The single set of signals appearing accordingly should be the general exhibition of the conformations produced by the hindered rotation, different from any of those two sets of signals revealed at $21^{\circ} \mathrm{C}$.

Furthermore, it could be deduced that the hindered rotation would be slower and slower along with the fall of temperature. At a certain low temperature, the rotation speed was low enough to produce a relatively stable conformation, which could also lead to a single set of signals corresponding to one of those two conformations at $21^{\circ} \mathrm{C}$. This compound was further measured at $-50^{\circ} \mathrm{C}$, and $-30^{\circ} \mathrm{C}$ to observe the change of its spectra at low temperature. As a result, the two sets of signals in $1: 1$ ratio observed at $21^{\circ} \mathrm{C}$ changed to those in $1: 0.3$ at $-30^{\circ} \mathrm{C}$, and even to an almost single set of signals at $-50^{\circ} \mathrm{C}$ (Fig. 1).

The above results supported the close correlation of its NMR behavior with temperature. Additionally, the effects of solvents were also investigated. At $21^{\circ} \mathrm{C}$, the ${ }^{13} \mathrm{C}$-NMR spectra were measured in DMSO- $d_{6}$, and acetone- $d_{6}$, respectively. The spectral complexity at the dimeric level was observed in both measurements. At $90{ }^{\circ} \mathrm{C}$ in Pyridine- $d_{6}$, the ${ }^{13} \mathrm{C}-\mathrm{NMR}$ spectra were also a single set of signals. These observations suggested that the solvents had no significant effect on its rotameric behavior.

As the major constituent of the antibacterial fraction, ${ }^{1)}$ GB1 was tested for its inhibitory effects against MRSA, and VRE, especially. This compound displayed antibacterial effects with minimum inhibitory concentration (MIC) of 32, and $128 \mu \mathrm{g} / \mathrm{ml}$, respectively. 


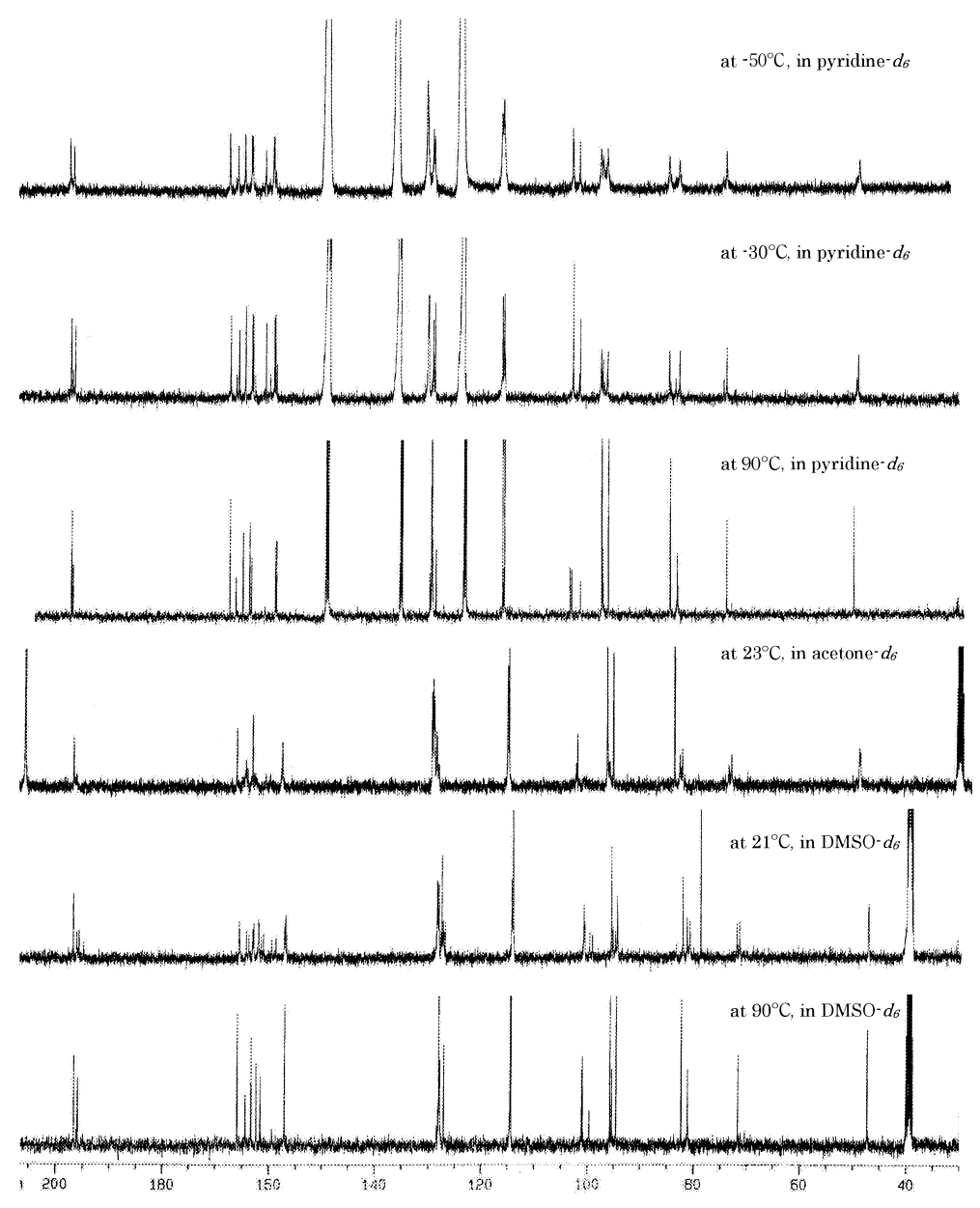

Fig. 1. The ${ }^{13} \mathrm{C}-\mathrm{NMR}$ Spectra Recorded at Different Temperatures and in Different Solvents

\section{Experimental}

General Procedures ESI-MS was recorded on a VG Auto Spec-3000 spectrometer. 1D- and 2D-NMR spectra were run on a Brucker AM-400 and a DRX-500 instrument with TMS as internal standard, respectively.

Plant Material The dried roots of $G$. kola were obtained at a local market in Lagos, Nigeria and authentiated by Dr. A. O. Adeoye, Department of Pharmacognosy, School of Pharmacy, College of Medicine, the University of Lagos, Lagos, Nigeria. A specimen (No LUH230) was deposited at the Lagos University Herbarium, Lagos, Nigeria.

Extraction and Isolation G. kola $(30 \mathrm{~g})$ was chopped into pieces and refluxed with methanol $(150 \mathrm{ml})$ for $2 \times 2 \mathrm{~h}$. The methanol extract was concentrated and successively extracted with hexane $(3 \times 150 \mathrm{ml})$, chloroform $(3 \times 150 \mathrm{ml})$, ether $(5 \times 150 \mathrm{ml})$, and $n$-butanol $(3 \times 150 \mathrm{ml})$. The ether extract containing the active anti-bacterial principal was subjected to silica gel column chromatography eluting with chloroform containing increasing concentration of methanol $(5-20 \%, \mathrm{v} / \mathrm{v})$. GB1 $(100 \mathrm{mg})$ was isolated from the chloroform/methanol $9: 1$ fraction by preparative thin layer chromatography on silica gel using the solvent system of chloroform/methanol $(9: 1, \mathrm{v} / \mathrm{v})$.

Antibacterial Assays The agar-diffusion method was used as an antibacterial screening test. Dried samples were dissolved in DMSO and $25 \mu \mathrm{l}$ aliquots were applied to wells on Mueller Hinton agar plates (BBL, Becton Dickinson and Co., Cockeysville, MD, U.S.A.), which have been inoculated with tested bacteria according to the standard protocol described by the $\mathrm{Na}-$ tional Committee of Clinical Laboratory Standards (1993, Document M7A3, Methods for dilution antimicrobial susceptibility tests for bacteria that grow aerobically). The plates were incubated at $35^{\circ} \mathrm{C}$ and the diameter of the inhibition zone was measured after $24 \mathrm{~h}$. DMSO without test compound served as controls and no inhibition was observed.

The minimum inhibitory concentration (MIC) was determined by the macrobroth dilution assay (National Committee of Clinical Laboratory Standards, 1993). Briefly, stock solutions $(5.12 \mathrm{mg} / \mathrm{ml})$ of compounds in DMSO were two-fold diluted in $0.5 \mathrm{ml}$ of Mueller Hinton broth. To these broths, $0.5 \mathrm{ml}$ of bacterial suspensions (106 superscript $6 \mathrm{cfu} / \mathrm{ml}$ ) was added. The tubes were incubated at $35^{\circ} \mathrm{C}$ for $24 \mathrm{~h}$. MIC was determined as the lowest concentration of the compound completely inhibited the growth of the test organism.

Acknowledgments This research is funded by the Hong Kong Jockey Club Charities Trust.

\section{References}

1) Taiwo O., Xu H. X., Lee S. F., Phytother. Res., 13, 675-679 (1999).

2) Wolinsky L. E., Sote E. O., Caries Res., 17, 253-257 (1983).

3) Wolinsky L. E., Sote E. O., Caries Res., 18, 216-225 (1984).

4) Cotterill P. J., Scheinmann F., Stenhouse I. A., J. Chem. Soc., Perkin Trans. I, 1978, 532-539 (1978).

5) Kabangu K., Galeffi C., Aonzo E., Nicoletti M., Messana I., Planta Medica, 53, 275-279 (1987).

6) Niwa M., Terashima K., Ito J., Aqil M., Heterocycles, 38, 1071-1076 (1994).

7) Niwa M., Ito J., Terashima K., Aqil M., Heterocycles, 38, 1927-1934 (1994).

8) Terashima K., Aqil M., Niwa M., Heterocycles, 41, 2245-2250 (1995).

9) Terashima K., Shimamura T., Tanabayashi M., Aqil M., Akinniyi J. A., Niwa M., Heterocycles, 45, 1559-1566 (1997).

10) Terashima K., Kondo Y., Aqil M., Waziri M., Niwa M., Heterocycles, 50, 283-290 (1999).

11) Iwu M. M., Igoboko O. A., Tempesta M. S., Fitoterapia, 61, 178-181 (1990).

12) Braide V. B., Fitoterapia, 64, 433-436 (1993).

13) Jackson B., Locksley H. D., Scheinmann F., J. Chem. Soc. (C), 1971, 3791-3804 (1971).

14) Ferrari J., Terreaux C., Kurtan T., Szikszai-Kiss A., Antus S., Msonthi J. D., Hostettmann K., Helv. Chim. Acta, 86, 2768-2778 (2003).

15) Kumar V., Brecht V., Frahm A. W., Planta Medica, 70, 646-651 (2004). 